\title{
WEATHERING THE STORM
}

\section{Tough questions for the Scorpions}

Jean Redpath, criminal justice research consultant redpath@iafrica.com

The 'Scorpions' are probably the most recognised law enforcement body in South Africa. Yet their existence appeared to be under threat during 2003 when highly placed figures suggested that they 'cherry-pick' their cases, and are open to political manipulation. There was even talk of disbandment or restructuring under the police on the grounds of unconstitutionality. While the Scorpions appear to have weathered that particular storm, the issues remain. Is there any substance to the accusations?

$\mathrm{T}$ he launch of the Scorpions was announced in September 1999, and the organisation became formally known as the Directorate of Special O perations (DSO) in January 2001 when its founding legislation was promulgated. ${ }^{1}$ The DSO is the investigative arm of South Africa's National Prosecuting Authority, falling under the authority of the National Director of Public Prosecutions, Bulelani $\mathrm{N}$ gcuka (referred to below as the 'N ational Director').

$\mathrm{High}$-profile since its inception, the organisation is generally viewed by the South African public as embodying the ultimate crime fighters. The DSO investigation into the arms deal concluded by the South African government in 1999, and its investigation into the role of the deputy president in this deal, upped this public profile considerably and highlighted the unresolved issues that have dogged the DSO since inception.

\section{The cherry-picking accusation}

Almost as soon as successful DSO cases began to be publicised, accusations of DSO 'cherry-picking' arose. Specifically, the DSO is accused of choosing to investigate and prosecute only matters which they are sure to win. Sometimes this accusation went further, to suggest the DSO had a tendency to take over cases already substantially investigated, taking all the credit for the subsequent successful conclusion of the matter. More generally, there is discomfort as to which cases become DSO 'matters' - in law enforcement language, uncertainty as to the DSO 's mandate.

It is easy to dismiss the accusations as 'sour grapes', but the very real uncertainty remains as to how a matter comes to be pursued by the DSO. What then, is the DSO 's mandate? Given the complexity of the answer to this question, it is unsurprising that uncertainty exists.

The legislation creating the DSO describes a legislative mandate encompassing a broad concept of organised crime - any crime committed in an "organised fashion" - which is so wide that just about any matter could be argued to fall under the DSO mandate. The legislation furthermore specifically retains all of the police's powers of investigation, so that this mandate is not exclusive to the DSO. Clearly, such a broad mandate is not practical for those on the ground who must put it into practice. The legislature appeared to have envisaged that a negotiated operational mandate would emerge, and that a Ministerial Committee, consisting solely of Cabinet members, created by 
the legislation would confirm procedures for the transferral of matters to the DSO. ${ }^{3}$

However, acrimony between the SAPS and DSO arose soon after the launch of the organisation. With the appointment in 2000 of Jackie Selebi as SAPS $\mathrm{N}$ ational Commissioner, a man who was keen to defend the reputation of the police and who clashed with the $\mathrm{N}$ ational Director, a negotiated mandate became unlikely. The Ministerial Committee never sat. As a result, the DSO was forced to carry out an internal case review, in which it considered whether the matters it had already taken on were appropriate or not. In doing so, the DSO came up with its own operational mandate - more in the nature of internal terms of reference - which outlines the requirements a case must meet before being taken on. This was dubbed "Circular O ne". ${ }^{4}$

In terms of Circular $\mathrm{O}$ ne, the first criterion is that the matter concerned must fall within the strategic focus areas of the DSO. These have been refined to include: drug trafficking, organised violence (including taxi violence, urban terror and street gangs), precious metals smuggling, human trafficking, vehicle theft and hijacking syndicates, serious and complex financial crime, and organised public corruption.

There are a further 14 general criteria or factors that must be considered, covering such questions as 'Is the criminal activity involved complex, and does it comprise at least five persons?' There are also financial thresholds that must be met. For example, a corruption matter has a threshold of R500,000, while serious economic offences must involve actual loss of $\mathrm{R} 5 \mathrm{~m}$ to meet threshold requirements.

All of these requirements must be met and considerations canvassed before the head of the DSO will authorise an investigation or 'declare a matter in terms of s28'. Prior to such an authorisation, no DSO members are designated to a case and DSO members do not, until designation, enjoy the DSO special powers of investigation, which include somewhat expanded powers of search and seizure.

This, then is the mandate of the DSO. While it does to some extent put to rest the cherry-picking accusation - no case which meets all of these requirements can by any stretch of the imagination be considered 'easy' to prosecute - it does provide many loopholes for the DSO to justifiably turn down the investigation of a case. Indeed, the major concern of the DSO head office does appear to have been to avoid being overloaded with trivial matters.

However, one of the main flaws from which this mandate suffers - arguably due to political circumstances beyond the control of the DSO - is that it has been drawn up without any outside input. The question of whether a case is taken on or not remains one which is settled internally, by the DSO alone. Furthermore, there seems to be no oversight body which on a regular basis reviews case selection. O utside accountability of the DSO as a whole rests entirely with the Minister of Justice and Constitutional Development, and with the justice portfolio committee of parliament.

\section{The constitutional question}

D uring 2003, some in government suggested that the DSO in its current form might be 'unconstitutional'. Again, it is tempting to dismiss such accusers as having ulterior motives. $\mathrm{N}$ evertheless, the basis for this claim appeared to be the constitutional provision which states that South Africa must have only one police force (the suggested cure for the defect is the removal of the DSO from the NPA to fall under the control of the SAPS). ${ }^{5}$

The first thing to note is that if the DSO were to be located anywhere other than under the NPA, it would no longer be the DSO as conceived - that is, a unit comprising prosecutors and investigators working together as a team on a daily basis, carrying investigations through to prosecutions seamlessly. N evertheless, some kind of secondment arrangement with prosecutors working with SAPS investigators could be set up to approximate DSO operation.

Yet the question remains a moot point - is the DSO, as conceived, constitutional? While an expert constitutional opinion cannot be offered, some relevant constitutional provisions can be discussed. The provision in question prohibits any other entity from operating as a police force - from having the 
"objective powers and functions" of the police. O nly in the matter of investigation of crime does the DSO overlap with the SAPS.

Yet each of the objectives, powers and functions of the police on their own are manifestly not exclusive to the police - for example, the object of "securing the inhabitants of the Republic" would also be shared by the SANDF. It could therefore be argued that the 'investigation of crime' on its own is similarly not the exclusive preserve of the SAPS. This would tend to suggest that the DSO within the NPA is not excluded from investigating crime. But is it empowered to investigate crime?

The constitution provides that the $\mathrm{N}$ ational $\mathrm{D}$ irector has the power to carry out any "necessary functions incidental to instituting criminal proceedings". It could be argued that this includes the further investigation of certain crimes to ensure successful prosecution. Many institutions other than the DSO carry out investigations incidental to their functions - such as the Auditor-G eneral, or the South African Revenue Service.

Furthermore, Parliament itself considered the question and took the unusual step of making its opinion clear: the preamble to the NPA amendment act creating the DSO says, "the constitution does not provide that the prevention, combating or investigating of crime is the exclusive function of any single institution".

But the constitutional provision regarding a single police force is a distraction from a more deepseated question of constitutional theory, which is relevant not only to the DSO alone but to the NPA as a whole - the question of the immense power of the National Director, and its impact on the principle of the separation of powers. That power which resides largely in prosecutorial veto - was greatly increased once the DSO was created, effectively providing the National Director with authority also over a powerful investigative tool.

\section{Separation of powers}

'Separation of powers' refers to the principle of democratic constitutional theory that the business of government should be divided along natural lines into the power to make law (legislative), the power to enforce law (executive), and the power to resolve disputes arising under law, including deciding on whether actions undertaken by the other two branches fall within the law (judicial). The idea is that each branch of government must have the power and the incentive to guard its own sphere and to counter the abuses of the other two.

In 1998 legislation was passed that gave South Africa a single, national prosecuting authority, in terms of which the $\mathrm{N}$ ational Director could veto the prosecutorial decisions of provincial directors - and indeed of any prosecutor. ${ }^{6}$ These powers were almost immediately subjected to constitutional scrutiny, but in 1996 the Constitutional Court held that this provision did not unjustifiably infringe the doctrine of separation of powers and that there were sufficient safeguards against the abuse of power by the $\mathrm{N}$ ational Director. ${ }^{7}$

However, in the modern state, a prosecutor, particularly a national prosecutor, plays a role that to some extent impinges on the principle of separation of powers. The DSO, as an entity of the NPA, falls directly under the National Director, and its decisions to prosecute are also subject to his veto. (Even were the DSO to fall under the SAPS, the $\mathrm{N}$ ational Director would still have a veto power over any prosecution).

The position of the prosecution service in any country is interesting in that close analysis reveals that it runs the risk of straddling both the executive and judicial spheres. The prosecution in reality has a quasi-judicial function (only those crimes it chooses are prosecuted, and only those it prosecutes run the risk of being convicted) yet it is firmly positioned under the executive branch of government.

The decision to prosecute a matter is not unduly problematic because whether a conviction is obtained depends in the final analysis on the judiciary; in theory, even a malicious prosecution will not succeed if the judiciary finds there is not enough evidence to prove the charge. However, a decision not to prosecute is more problematic, as there is no input into the outcome of such a decision from another branch of government. 
In theory, the failure on the part of the prosecution to carry out its obligations, in particular, by declining to pursue allegations of wrongdoing by members of the executive, leaves only recourse to the legislature, to whom the prosecution is accountable. ${ }^{8}$ Parliament can therefore call the prosecution to account for the decisions it takes, particularly decisions to prosecute or not to prosecute. Although this is theoretically possible, an academic paper has argued that in political systems where the president is elected by the legislature and therefore by the majority party in Parliament, the probability of Parliament calling the prosecution to account for its failure to prosecute is low. ${ }^{9}$ This thesis appears to hold true in South Africa, where the majority party in parliament effectively elects the president.

A person who feels aggrieved by the prosecuting authority's decision not to prosecute may also opt to institute a private prosecution. How ever, this could become particularly complex and expensive for an unsuccessful private prosecutor.

\section{The political manipulation accusation}

Closely allied to the question of separation of powers are the accusations levelled against the DSO that it is open to political manipulation. Such accusers would say that given the reputation for excellence of the DSO, the mere fact that an investigation is carried out against a particular person suggests guilt and could be used to tarnish that person in the public mind. On the other hand, the DSO could also decline to investigate or prosecute a matter when it should indeed do so, in order to protect particular individuals.

In essence, these concerns can be reduced to the question of whether the DSO is at the same time independent (acts against the executive or legislature when necessary) impartial (refrains from acting maliciously against political opponents of the executive) and accountable (answerable for its actions). These traits are neither mutually exclusive nor mutually compatible. For example, consider the situation in which the M inister of Justice and Constitutional Development, to whom the DSO is accountable, is implicated in an investigation.
This balancing of independence, impartiality and accountability is an extremely difficult one. In considering whether the DSO has succeeded in maintaining the balance, there are two questions: first, whether the DSO has in fact thus far behaved independently, impartially and accountably, and second, whether the DSO is structured such that at any stage in the future, it is unlikely to fail on any of these points.

Without access to detailed information on the matters with which the DSO has engaged, it is extremely difficult to judge the first question of actual independence, impartiality, and accountability. The mere fact of the existence of a DSO investigation into the arms deal - which is likely to implicate members of the executive - is cited as evidence of the DSO 's independence. However, similarly, the refusal to prosecute the Deputy President, combined with the public tarnishing of his name, is cited by others as evidence of partiality. Again, without more in-depth knowledge, these questions are almost impossible to judge.

But in an unknown future with unforeseen facts and unknown players, how prone would the DSO be to fail to be independent, impartial, or accountable? After all, President M beki has only one more term, and $\mathrm{N}$ gcuka's tenure ends in 2008.

The DSO as it is structured is overshadowed by the fact that the N ational Director, its de facto head, is dependent on the President's continued good opinion that he is a fit and proper person, to avoid being removed from office. It could, however, be argued that this requirement protects the $\mathrm{N}$ ational Director from outside interference. $\mathrm{He}$ is appointed for a non-rewewable term of ten years at the salary of at least a High Court judge, and the grounds under which the president can remove or suspend him are limited..$^{10}$ Also, such a decision by the president is subject to ratification by parliament.

Furthermore, while the DSO is accountable to the $M$ inister of Justice and Constitutional Development, and to parliament, this form of accountability is insufficient and perhaps even counter-productive (on the independence front) when decisions on 
whether to investigate (not to mention prosecute) members of the executive and legislative arms of government are at issue, if the executive and legislature are closely intertwined as they are in South Africa. The M inisterial Committee created by the DSO legislation, which inter alia may determine "where necessary the responsibility of the DSO in respect of specific matters"12 is fundamentally flawed in that it consists solely of Cabinet Ministers. By contrast, the U nited Kingdom's National Crime Squad (NCS) is directed by an NCS Service Authority consisting of 11 members, none of whom are high-ranking members of the executive, five of whom are entirely independent, and four of whom are elected by associations of police officers.

Consider that Italian Prime Minister Silvio Berlusconi in 2003 succeeded in getting his parliament to pass legislation immunising him from prosecution while he remained in office. (Italy's Constitutional Court subsequently declared the law unconstitutional.) How much easier for him if he could have got a committee consisting of his Cabinet to instruct investigators not to pursue the corruption matter which implicated him?

Lastly, there is no provision for misconduct by individual members of the DSO to be investigated by an independent body. Alleged misconduct of SAPS members as well as those of municipal police forces fall under the mandate of the Independent Complaints Directorate.

\section{Recommendations}

What is clear is that the current legislative structure of the DSO makes its independence, accountability and impartiality almost entirely dependent on the integrity of its officers and of the $\mathrm{N}$ ational Director. While the incumbents may indeed thus far have acted blamelessly, what could improve the situation (and safeguard the future) while not interfering with the ability of the DSO to do its job?

- An independent committee consisting partially of persons outside of the executive and legislature should exercise (post facto) oversight in respect of DSO case selection (the exercise of its mandate), and review the general conduct of investigations and prosecutions after their conclusion.
- A decision not to prosecute should be reported to the committee after the conclusion of a DSO investigation, and should be reviewable by the Supreme Court of Appeal at the instance of the committee.

- Removal of the National Director by the President should only be possible after confirmation by the Supreme Court of Appeal.

- Alleged misconduct by individual DSO members should fall under the mandate of the Independent Complaints D irectorate.

The DSO is an innovation in South African law enforcement which has had a profound impact on the investigation of complicated cases. While allegations of cherry-picking, at least since the adoption of Circular O ne, do not appear to be founded, DSO case selection is a laborious and opaque process. The legal infrastructure within which the DSO is situated is not without problems, especially in respect of ensuring a balance of the DSO 's independence, accountability and impartiality.

\section{Endnotes}

1 National Prosecuting Authority Amendment Act 61 of 2000.

2 'O rganised fashion' includes the planned, ongoing, continuous or repeated participation, involvement or engagement in at least two incidents of criminal or unlawful conduct that has the same or similar intents, results, accomplices, victims or methods of commission, or otherwise are related by distinguishing characteristics.

3 See s31(1) N ational Prosecuting Authority Act 61 of 1998 as amended.

4 The $\mathrm{O}$ ffice of the Head of O perations: DSO. Circular:1. Effective Date 8 N ovember 2001. Signed: Acting Investigating Director Adv. LF McCarthy 7-112001.

5 See for example, Skerpioene word dalk deel van polisie, sê M beki, Die Burger, 30 July 2003.

6 National Prosecuting Authority Act 32 of 1998.

7 See s179, Constitution of the Republic of South Africa Act 108 of 1996. The Constitutional Court confirmed this provision of the Constitution at paragraphs 140 and 141 in CCT 23/96, Certification of the Constitution of the Republic of South Africa, 1996.

8 See s35(1) of the National Prosecuting Authority Act 61 of 1998. However, the Minister of Justice and Constitutional Development exercises final responsibility over the prosecution, in terms of s 179(7) of the Constitution of the Republic of South Africa Act 108 of 1996. 
9 Van Aaken, Salzbuger \& Voigt, The Prosecution of Public Figures and the Separation of Powers:

Confusion within the Executive Branch, German Working Papers in Law and Economics, Paper 11, Volume 2003.

10 The president may remove the $N$ ational Director on the grounds of the National Director's continued illhealth, misconduct, incapacity to carry out his duties efficiently, or on the grounds that the National Director is no longer a fit and proper person to hold office. See s12(6)(a) National Prosecuting Authority Act 32 of 1998.

11 J Chafetz, The Independent Counsel after $\mathrm{N}$ ixon, Yale Political Q uarterly 19(3), 1998.

12 See s31(1)(c)(i) National Prosecuting Authority Act 32 of 1998. 